\title{
Genetic diversity of pomegranate germplasm collection from Spain determined by fruit, seed, leaf and flower characteristics
}

Juan José Martínez, Pablo Melgarejo, Pilar Legua, Francisco García, Francisca Hernández

Background . Miguel Hernandez University ( Spain ) created a germplasm bank of the varieties of pomegranate from different Southeastern Spain localities in order to preserve the crop's wide genetic diversity. Once this collection was established, the next step was to characterize the phenotype of these varieties to determine the phenotypic variability that existed among all the different pomegranate genotypes, and to understand the degree of polymorphism of the morphometric characteristics among varieties.

Methods. Fifty-three pomegranate (Punica granatum L.) accessions were studied in order to determine their degree of polymorphism and to detect similarities in their genotypes. Thirty-one morphometric characteristics were measured in fruits, arils, seeds, leaves and flowers, as well as juice characteristics including content, $\mathrm{pH}$, titratable acidity, total soluble solids and maturity index. ANOVA, principal component analysis, and cluster analysis showed that there was a considerable phenotypic diversity (and presumably genetic).

Results. The cluster analysis produced a dendrogram with four main clusters. The dissimilarity level ranged from 1 to 25, indicating that there were varieties that were either very similar or very different from each other, with varieties from the same geographical areas being more closely related. Within each varietal group, different degrees of similarity were found, although there were no accessions that were identical. These results highlight the crop's great genetic diversity, which can be explained not only by their different geographical origins, but also to the fact that these are native plants that have not come from genetic improvement programs. The geographic origin could be, in the cases where no exchanges of plant material took place, a key criterion for cultivar clustering.

Conclusions. As a result of the present study, we can conclude that among all the parameters analyzed, those related to fruit and seed size as well as the juice's acidity and pH had the highest power of discrimination, and were, therefore, the most useful for genetic characterization of this pomegranate germplasm banks. This is opposed to leaf and flower characteristics, which had a low power of discrimination. This germplasm bank, more specifically, was characterized by its considerable phenotypic (and presumably genetic) diversity among pomegranate accessions, with a greater proximity existing among the varieties from the same geographical area, suggesting that over time, there had not been an exchange of plant material among the different cultivation areas. In summary, knowledge on the extent of the genetic diversity of the collection is essential for germplasm management. In this study, these data may help in developing strategies for pomegranate germplasm management and may allow for more efficient use of this germplasm in future breeding programs for this species. 
1 Genetic diversity of pomegranate germplasm collection from Spain determined by fruit,

3 Juan José Martínez-Nicolas, ${ }^{1, *}$, Pablo Melgarejo ${ }^{1}$, Pilar Legua ${ }^{1}$, Francisco Garcia-Sanchez ${ }^{2}$ \&

4 Francisca Hernández ${ }^{1}$

5 Plant Science and Microbiology Department, Universitas Miguel Hernández. Ctra Beniel 3.2, 03312 Orihuela, 6 Alicante, Spain.

$7 \quad{ }^{2}$ Centro de Edafología y Biología Aplicada del Segura, CEBAS-CSIC, Murcia, España

8

9 * Corresponding author: Tel: +34966749691; Fax: +34966749693; E-mail:

10 juanjose.martinez@umh.es

11 Short Title: Genetic diversity of pomegranate 
14 Abstract

Background. Miguel Hernandez University (Spain) created a germplasm bank of the varieties of pomegranate from different Southeastern Spain localities in order to preserve the crop's wide genetic diversity. Once this collection was established, the next step was to characterize the phenotype of these varieties to determine the phenotypic variability that existed among all the different pomegranate genotypes, and to understand the degree of polymorphism of the morphometric characteristics among varieties.

Methods. Fifty-three pomegranate (Punica granatum L.) accessions were studied in order to determine their degree of polymorphism and to detect similarities in their genotypes. Thirty-one morphometric characteristics were measured in fruits, arils, seeds, leaves and flowers, as well as juice characteristics including content, $\mathrm{pH}$, titratable acidity, total soluble solids and maturity index. ANOVA, principal component analysis, and cluster analysis showed that there was a considerable phenotypic diversity (and presumably genetic).

Results. The cluster analysis produced a dendrogram with four main clusters. The dissimilarity level ranged from 1 to 25 , indicating that there were varieties that were either very similar or very different from each other, with varieties from the same geographical areas being more closely related. Within each varietal group, different degrees of similarity were found, although there were no accessions that were identical. These results highlight the crop's great genetic diversity, which can be explained not only by their different geographical origins, but also to the fact that these are native plants that have not come from genetic improvement programs. The geographic origin could be, in the cases where no exchanges of plant material took place, a key criterion for cultivar clustering. Conclusions. As a result of the present study, we can conclude that among all the parameters analyzed, those related to fruit and seed size as well as the juice's acidity and $\mathrm{pH}$ had the highest power of discrimination, and were, therefore, the most useful for genetic characterization of this pomegranate germplasm banks. This is opposed to leaf and flower 
39 characteristics, which had a low power of discrimination. This germplasm bank, more

40 specifically, was characterized by its considerable phenotypic (and presumably genetic) diversity

41 among pomegranate accessions, with a greater proximity existing among the varieties from the

42 same geographical area, suggesting that over time, there had not been an exchange of plant

43 material among the different cultivation areas. In summary, knowledge on the extent of the

44 genetic diversity of the collection is essential for germplasm management. In this study, these

45 data may help in developing strategies for pomegranate germplasm management and may allow

46 for more efficient use of this germplasm in future breeding programs for this species. 


\section{Introduction}

Pomegranate is a deciduous fruit tree, and its cultivation has been greatly expanded into several countries in recent years, especially those with a Mediterranean-like climate. In Spain, for example, the total acreage used today for its cultivation is about 2,791 ha, with an annual production of about 43,324 metric tons (MAGRAMA, 2014). The growing interest in this fruit is not only due to the fact that it is pleasant to eat, but it is also because it is considered to be a functional product that has been shown to be beneficial to human health, as it contains several types of substances that are useful in disease prevention (Melgarejo and Artés, 2000; Melgarejo and Salazar, 2002; Cam et al., 2009; Legua et al., 2012; Zaouay et al., 2012; Calani et al., 2013 and Melgarejo-Sánchez et al., 2015). Therefore, the demand for this fruit has increased in the last 10 years, as it has been used in industrial processing to obtain pomegranate juice, jams, vegetable extracts, etc. (Melgarejo-Sánchez et al., 2015).

The pomegranate's place of origin is considered to be Central Asia, from where it has spread to the rest of the world (Mediterranean Basin, Southern Asia and several countries of North and South America). It is a temperate-climate species that requires high temperatures to mature properly, but it is also easily spread in arid and semi-arid areas of the world, as it is tolerant to salinity and water scarcity, factors that usually limit the growth of other agronomical crops in these areas. Its successful adaptation to abiotic stress conditions, which characterize the Spanish Mediterranean climate, has led to its wide dispersion in this geographical area and to the appearance of a multitude of new, local individuals over time beginning with specific varieties (Naeini et al., 2004, Naeini et al., 2004, Martínez et al., 2006, Sarkhosh et al., 2006).

These new varieties have been grouped under the same denomination, however, each one of them could have different agronomic characteristics as compared to their original progenitor. For example, Melgarejo and Salazar (2003) observed that under the denomination "Mollar de Elche" (ME) there were varieties with different agronomic characteristics. In order to better identify the 
76 fruit, Verma et al. (2010) have mentioned the importance of agronomically-characterizing of

77 varieties of a specific cultivar from the place where they originated to the areas where they

78 disseminated, as being useful for understanding the evolution of the cultivar and for maintaining

79 the biodiversity of the varieties, as well as for the improvement of agronomic characteristics of

80 the crops.

In 1992, the Miguel Hernandez University created a germplasm bank of the varieties of pomegranate found in Southeastern Spain in order to preserve the crop's wide genetic diversity. Since its creation, many local types have been inventoried, described and planted in the experimental farm at EPSO (Escuela Politécnica Superior de Orihuela- Miguel Hernandez

University, Alicante). Currently, the collection contains 59 accessions that have been collected from different growing areas in Spain, representing about 16 local denominations (Melgarejo, 1993). Once this collection was established, the next step was to determine its genetic biodiversity, and to classify the germplasm bank according to their agronomic characteristics rather than according to only a botanical point of view, as pomegranate consumption is important in both the fresh-fruit market and the processing industry. For this, the evaluation of the different morphometric and fruit characteristics was necessary, as this would a better describe and compare the genetic diversity of this germplasm collection. Mars and Marrakchi (1999) revealed the usefulness of measuring morphometric and chemical compound fruit variables such as weight, length, diameter, external color, seed number, length and diameter of the calyx, juice's volume, color, $\mathrm{pH}$, total soluble solids TSS (g/l) and total acidity TA $(\mathrm{g} / \mathrm{l})$, in order to determine the genetic diversity of a pomegranate germplasm bank in Tunisia, composed of thirty pomegranate (Punica granatum L.) accessions.

To study the genetic diversity of the germplasm bank, microsatellite markers have also been used. Singh et al. (2015) validated the efficiency of this molecular tool on a pomegranate collection comprised of 88 accessions (37 domesticated and 51 wild). The study measured the structure of 
101 the population among the wild and domesticated accessions. Ophir et al. (2014), in a study using 102 Single Nucleotide Polymorphism (SNP) Markers on 105 worldwide pomegranate accessions, 103 located in the pomegranate germplasm collection at the Newe Ya'ar Research Center in northern

104 Israel, observed that genetic diversity was primarily due to the geographic location of origin.

105 In the present work, we focus on morphometric and chemical compound measurements that will 106 allow us to gain basic but needed knowledge on the agronomic characteristics of this 107 pomegranate germplasm collection (grown under homogeneous conditions). If the phenotypic 108 variability is found to be high, then the assumption is made that they are also genotypically 109 different. These results could lead us to further characterize this collection through genetic 110 analysis.

111 In our study, aside from the parameters mentioned above (Mars and Marrakchi, 1999), 112 parameters related to seeds, leaves and flowers were also measured, in order to have more 113 complete information for determining the phenotypic and presumably genetic diversity among all 114 the accessions. Therefore, the objective of this research was to determine the phenotypic 115 variability that exists among all the different genotypes of Southeastern Spanish pomegranate, to understand the degree of polymorphism of the morphometric characteristics among varieties, and

117 to establish the existing variability among accessions from the same family. Also, this research 118 work had the advantage that the data used were taken on three consecutive years from trees that 119 were planted in the same field thereby avoiding any edaphoclimatic effect on the results.

121 Material and methods

122 Plant material

123 The areas prospected and the germplasm collecting procedures were as reported in Melgarejo 124 (1992). Fifty-three accessions, representing 16 denominations, were included in the present study 
125 (Fig. 1, Table 1). They were represented by twenty-five year old adult trees, maintained within 126 the same collection in Alicante in the Southeast region of Spain (Melgarejo, 1993).

Pomegranate trees were grown under homogeneous conditions in a loamy clay soil with a spacing of $5 \times 4 \mathrm{~m}$. A drip irrigation system was used for fertigation purposes. The collection was

located in the experimental orchards belonging to the Miguel Hernández University, located in the province of Alicante, Spain (latitude: $38^{\circ} 03^{\prime} 50^{\prime \prime} \mathrm{N}$, longitude: $02^{\circ} 03^{\prime} 50^{\prime \prime} \mathrm{W}$ and an altitude of $26 \mathrm{~m}$ above sea level). According to Papadakis' classification (Papadakis, 1966), the experimental plot had a subtropical Mediterranean climate. The annual mean temperature was 19 ${ }^{\circ} \mathrm{C}$, with mild winters $\left(11^{\circ} \mathrm{C}\right.$ in January) and hot summers $\left(28{ }^{\circ} \mathrm{C}\right.$ in August). A low annual precipitation of $300 \mathrm{~mm}$ was recorded, mostly falling in spring and autumn.

\section{Characters studied}

The studies were based on measuring the characteristics of fruits, seeds, leaves and flowers. Morphometric measurements and chemical analyses were carried out on samples from 20 mature fruits, 25 seeds, 50 leaves and 25 flowers from each tree per variety, using a total of four trees per variety. The study was conducted over three consecutive years, and the following variables were measured:

Fruits. Fruit weight (FW), expressed in g; equatorial diameter (FD1), expressed in mm; calyx diameter (FD2), expressed in mm; fruit height without calyx (FL1), expressed in mm; total fruit height (FL2), expressed in mm; calyx height (FL3), expressed in mm; number of carpels (Nc) counted on the equatorial section; rind weight plus weight of carpellary membranes (PcMc), expressed in $\mathrm{g}$; skin thickness (Ec), expressed in $\mathrm{mm}$ (measurements were performed on two opposite sides in the equatorial plane); aril yield calculated as $(\mathrm{Rs})=[\mathrm{FW}-(\mathrm{PcMc}) / \mathrm{FW}] \mathrm{x} 100(\%)$.

Diameters, fruit height and skin thickness were measured with an electronic digital slide gauge (Mitutoyo), accurate to $0.01 \mathrm{~mm}$. Fruit weights and Rind weight plus weight of carpellary membranes were measured with a digital scale (Sartorius Model BL-600) accurate to $0.1 \mathrm{~g}$. 
151 homogenized sample in every sampling year. The following seed characteristics were studied 152 (Martínez, et al. 2006): maximum width (Sw) and length (SL), measured with a digital caliper (Mitutoyo) accurate to $0.01 \mathrm{~mm}$; aril weight $(\mathrm{SW})$, determined with a precision weighing device (Mettler AJ50) accurate to $0.0001 \mathrm{~g}$; juice volume (JV), using an electric extractor and a seed sample of $100 \mathrm{~g}$; total soluble solids (TSS) ( ${ }^{\circ}$ Brix), determined with an Atago N-20 refractometer at $20{ }^{\circ} \mathrm{C}$; total acidity, expressed as citric acid (AT), determined with an acid-base potentiometer and $\mathrm{pH}$; and maturity index $(\mathrm{MI}=\mathrm{TSS} / \mathrm{TA})$.

The most current classification that has been established for Spanish varieties (Melgarejo, 1993) were used: Sweet varieties: MI = 31-98; Sour-sweet varieties: MI = 17-24; Sour varieties: MI = 5-7. Three repetitions per clone and year were carried out.

Seeds: The parameters measured in the seeds (woody portion) were: maximum width (w) and length (1), measured with the same digital caliper as above; weight of the woody portion (wpw) of each seed using the above-mentioned precision balance; woody portion index (wpi), determined from the wpw/SW ratio $100(\%)$;

Leaves: The leaves studied were collected in September, by choosing 50 adult leaves per tree, normal and leaves that sprouted in the spring. This sampling was done in the four cardinal directions of the tree. The length measurements of the leaves were performed with a digital caliper (Mitutoyo) accurate to $0.01 \mathrm{~mm}$. The leaf surface area was determined with an image analyzer "Digital Image Analysis System" Delta-T model. The measured variables were: LW, leaf width (mm); Ll, blade length (mm); Lt, total length of the leaf (mm); Lp, petiole length (mm); LS, leaf surface area $\left(\mathrm{mm}^{2}\right)$.

Flower. The flowers were randomly sampled during the period of full flowering in the mid-May, taking a total of 25 flowers per tree from four trees. This sampling was done in the four cardinal directions of the tree. Length measurements were performed using a digital caliper 
175 (Mitutoyo) accurate to $0.01 \mathrm{~mm}$. The measured variables were: FD, flower diameter (mm); FL,

176 flower length (mm); NP, number of petals; Ns, number of sepals; LP, petal length (mm); WP, 177 petal width (mm); LS, style length (mm); NS, number of stamens.

179

180

181

182

183

184

185

186

187

188

189

190

191

192

193

194

195

196

197

198

199

\section{Statistical analysis}

The results were analyzed using the SPSS 22.0 software program for Windows (SPSS Science, Chicago, IL, USA). The differences between cultivars $(\mathrm{P}<0.05)$ found after analyzing the different parameters studied were evaluated by analysis of variance (ANOVA). The mean values measured for each parameter were used to perform: a) a principal component analysis (PCA) and b) a clustering of cultivars into similarity groups using Ward's method for agglomeration and the squared Euclidean distance as a measurement of dissimilarity.

\section{Results and discussion}

The data showed that the characters studied were highly variable, not only among the different varietals, but also among the different varieties that comprised these groups (Tables 2, 3, 4, and 5). The morphometric characters that had the greatest variability were in general those related to the fruit, arils and seeds. These characteristics will now be presented. The average fruit weight (FW) oscillated between $325 \mathrm{~g}$ (varietal group ME) and 414g (varietal group CRO).

These data shows that the average weight of Spanish pomegranates is less than the Turkish (Caliskan and Bayazit, 2013) or Moroccan (Martinez et al., 2012) varieties. The average weight of the arils varied between $0.39-0.55 \mathrm{~g}$, and the production between $56-62 \%$, which is similar to values from Iranian (Tehranifar et al. 2010) or Turkish (Caliskan and Bayazit, 2013) pomegranates, but below the Moroccan Sefri and Ounk Hman varieties (Martínez et al., 2012). The total soluble solids (TSS) varied between 12.6\% (CRO groups) and 15.3\% (MA group), which shows that the Spanish varieties are in general less sweet than other varieties such as the 
200 Turkish 'Eksi' (18.5\%; Caliskan and Bayazit, 2013). However, the Spanish varieties are less

201 acidic than those found in other countries, as shown by acidity values that oscillated between $202 \quad 0.21-0.48 \%$.

203 Other varieties such as "Jabal" from Oman (Al-Said et al. 2009), Iranian varieties (Tehranifar et 204 al. 2010) or the Turkish 'Lifani 2' variety (Caliskan and Bayazit, 2013) have greater acidity. The 205 maturity index (MI) varied between 37.6 (varietal group PTO) and 72.2 (MO group), while in the 206 Moroccan varieties these values usually oscillated between 37.4-77.6 (Martínez et al., 2012) and 207 this range tends to be wider among the Turkish varieties, which oscillate between 3.4-65.4 208 (Caliskan and Bayazit, 2013).

The leaf surface area (LS) results from our study oscillated between $7.35 \mathrm{~cm}^{2}$ (varietal groups $\mathrm{CRO}$ and $8.60 \mathrm{~cm}^{2}$ (MO group); the flower diameter (FD) varied between $10.6 \mathrm{~mm}$ (varietal group CRO) and $17.0 \mathrm{~mm}$ (ADO group), while the number of stamens varied between 245.8 (ME group) and 348.5 (ADO group). When analyzing the leaf and flower data, a lower variability was seen among varietal groups as compared to the variables measured in fruits and arils, and therefore had less discriminating power.

The PCA results revealed the existence of a high amount of variability among different varietal groups and among the varieties within each group, according to different morphometric and chemical characteristics that were measured in this research work.

Therefore, the findings from the pomegranate genotype grouping after the PCA were mainly based on the first three PCs, which accounted for $53.75 \%$ of the variability observed, with 27.77\% (eigenvalue, 9.99), 17.49\% (eigenvalue, 6.30), and 8.49\% (eigenvalue, 3.06) for PC1, PC2 and PC3, respectively (Fig.2). We defined values above 0.20 as significant for important parameters (Table 6).

223 The most important variables integrated by PC1 were fruit weight (FW), length (FL1, FL2), diameter (FD1) and arils. The weights of PC1 for leaf and flowers characteristics were less 
important. PC1 mainly separated the cultivars by the shape and size of their fruits and arils, with the groups composed by the cultivars PTO, CRO, PTB1 and ADO being the ones that had the largest fruits and arils (Figure $2 \mathrm{~A}, 4^{\text {th }}$ quadrant- $4 \mathrm{C}$ ), with the accession group ME being the one with the smallest sizes (Figure $2 \mathrm{~A}, 3^{\text {rd }}$ quadrant-3C). Other more recent and similar studies have shown that component PC1, the weight and shape of the fruit, is one of the main variables that differentiate the pomegranate genotypes, as found in studies performed in Croatia (Radunic et al., 2015) and Turkey (Caliskan and Bayazit, 2013).

PC2 explains, overall, the rind weight plus the weight of carpellary membranes (and therefore aril yield), the woody portion index of the arils (seeds), the leaf area and the length of the fruit, flowers, petals and sepals, as well as juice acidity ( $\mathrm{pH}$ and AT). But overall, this component differentiated the varieties by the acidity of their juice as well as their woody portion index. Figure 2A and 2C shows how varietals $\mathrm{BO} 1$ and $\mathrm{BA} 1$, which have a sour flavor, were grouped on the upper part of the first quadrant of the figure. Likewise, the varieties found in the first and second quadrant have a greater index of woody tissue.

PC3 integrated characters related with the shape and size of the flowers (FD, FL, NP, WP, Ns), leaf shape (LW, L1/LW), skin thickness (Ec) and the maturity index (MI) (Table 6), although this component was less significant than PC1 and PC2. The other flower and leaf characteristics were not so important in the present study.

The cluster analysis produced a dendrogram with four main clusters (Figure 3). The dissimilarity level (d) ranged from 1 to 25 , revealing that there was a great degree of similarity/dissimilarity among varieties. The first cluster (I) included the ME group's cultivars (21 accessions), as well as the variety MO2, which was more similar to varieties from the ME group than to its own varietal group (MO). All of these fruits were medium sized (275.9-356.1 g), had a low-acidity juice, and high maturity indices in general (Table 3). As previously shown, the 
249 varieties from these groups were placed on the $3^{\text {rd }}$ quadrant $(3 \mathrm{C})$ in the PC1 and PC2 principal 250 component analysis graphic shown in Figure 2A.

251 The second cluster (II) grouped cultivars BA1 and BO1, which were characterized by 252 having medium-large fruit, high juice acidity and woody portion index. The dendrogram showed that these varieties were very similar, even though they came from different locations. These results can be found on the upper right part of the first quadrant (1C) (Figure 2A and 2C).

The third cluster (III) was the most-heterogeneous group, as it was composed by 16 varieties from various locations, with fruits that were medium-large in size (331.5-436.5 g), and sweet juice (Tables 2 and 3). The dendrogram shows that there was a high degree of similarity between these 16 varieties, but at the same time, among these varieties, this similarity was greater between those that came from the same location or geographical area. These were mostly located in the second quadrant $(2 \mathrm{C})$ on Figure $2 \mathrm{~A}$.

The last group (IV) was composed by 12 varieties, all of them from the same geographical area. As a whole, the varieties in this cluster were more similar to themselves than the varieties from clusters I and III (Figure 3). The cluster IV varieties were characterized by their heavier fruit (358.8-464.2 $\mathrm{g} /$ fruit), and their large seeds (0.4-0.7 $\mathrm{g} / \mathrm{seed}$; Table 2). Most of the varieties from this group were placed in the fourth quadrant (Figure 2A) and on the first and fourth quadrant of Figure 2B, in the principal component analysis results.

In summary, this principal component and cluster analysis revealed two important results. First, in this pomegranate germplasm collection from Southeastern Spanish, there was a considerable variability among ascensions that may be mainly due to recombination (resulting from outcrossing) combined with sexual and vegetative propagation that occurred over a long period of time, as well as uncontrolled spread of plant material, as pomegranate is partially crosspollinated (Mars, 1996, Jalikop and Sampath, 1990 and Martínez et al. 2009). Second, within the 
273 group of cultivars 'ME', 'MO', 'MA', 'PTO' or 'ADO', a high degree of heterogeneity was 274 observed.

It is therefore possible to think that all these groups could be "variety-population" (Boulouha et al., 1992; Tous et al., 1995; Mars and Marrakchi, 1999), defined as plant material that although genetically different, have a certain degree of phenotypic resemblance. It is also interesting to point out that within the varieties analyzed, the four groups obtained in the cluster analysis (Figure 3) coincided almost completely with their geographical origin. Therefore, in those cases where exchanges of plant material had not been the case, the geographical origin could be a determining criteria for the grouping of the varieties, except for MO2, BA1, BO1, PG and PTO5 (Figure 3). This is in agreement with results reported for other fruit species (Barbagollo et al., 1997), but also contradicts the grouping criteria obtained by Mars and Marrakchi (1999), where the geographical origin was not a determining factor for explaining the phenotypic variability of the pomegranate diversity in Tunisia. These authors have suggested that the geographical origin was not determinant because over time, there had been an exchange of plant material between the different growing areas. Zhao et al. (2013), in a study performed on 46 pomegranate cultivars, also indicated that cultivars were not clustered according to their morphological traits, agronomic traits, or geographic origin. Some authors have pointed to several causes for these inconsistencies, including: (1) the reproducibility of gene mutations caused the same mutation to emerge repeatedly in the distantly-related individuals from different areas (Zhu, 2002); (2) the amplified polymorphic loci were not parts of the genes responsible for these morphological or the agronomic traits (Jbir et al., 2008 and Ebrahimi et al., 2010;) and (3) the quantitative traits were significantly influenced by the environment (Zhu, 2002).

In this germplasm bank, no identical accessions were found within a single group, as shown in the ANOVA results on table 5, as significant differences were found between the accessions belonging to a single group in most of the parameters analyzed, except for the juice 
characteristics, where differences in $\mathrm{pH}$, TSS, TA and MI were observed only in the PTO group among its seven accessions. Among all the groups analyzed, ME was stood out, as there were significant differences in all the physical parameters measured in the fruits among its accessions. This evidences the great genetic diversity that exists even within a single group, which could be explained not only by its different geographical origin, but also by the fact that it is native material that has been developing for many years, and has not suffered recombination with native material from other geographical areas. The data from this experiment also further confirmed the results from a previous study performed by Melgarejo et al (2009) which evaluated the genetic diversity of pomegranate cultivars by using Restriction Fragment Length Polymorphisms (RFLP) and Polymerase Chain Reaction (PCR) techniques. Ten pomegranate accessions from the varietal groups Mollar de Elche, Mollar de Albatera, Mollar de Orihuela, Valencianas and Bordes were evaluated, resulting in different genetic profiles for the different groups as well as for the accessions within a single group. Other studies on pomegranate have shown the large genetic variability of this crop by using molecular techniques such as simple sequence repeats markers (SSR, Ferrara et al., 2014; Pirseyedi et al., 2010, Hasnaoui et al., 2012), random amplified polymorphic DNA (RAPD, Hasnaoui et al. 2010, Narzary et al. (2009), microsatellite markers (Singh et al., 2015), or single-nucleotide polymorphism (SNP) markers Ophir et al. (2014).

\section{Conclusions}

As a result of the present study, we can conclude that among all the parameters analyzed, those related to fruit and seed size and the juice's acidity and $\mathrm{pH}$ were what had the highest power of discrimination, and, are therefore the most useful for genetic characterization studies of pomegranate germplasm banks. This is opposed to leaf and flower characteristics, which had a low power of discrimination. This germplasm bank, more specifically, was characterized by its 
considerable phenotypic (and presumably genetic) diversity among pomegranate accessions, with a greater phenotypic proximity existing among the varieties from the same geographical area, suggesting that over time, there has not been an exchange of plant material among the different growing areas. Also, within the same varietal group, a great variability was found, as no identical accessions were found. In general, knowledge on the extent of the genetic diversity found in the collection is essential for germplasm management. In this study, these data may help in the developing of strategies for pomegranate germplasm management and may allow for a more efficient use of this germplasm in future breeding programs for this species.

\section{References}

Al-Said, FA, Opara, LU, Al-Yahyai, RA. 2009. Physico-chemical and textural quality attributes of pomegranate cultivars (Punica granatum L.) grown in the Sultanate of Oman. Journal of Food Engineering 90: 129-134.

Barbagallo MG, Di Lorenzo RM, Crescimanno FG. 1997. Characterization of carob germplasm (Ceratonia siliqua L.) in Sicily. Journal of Horticultural Science 72: 537-543.

Boulouha B, Loussert R, Saadi R. 1992. Etude de la variabilité phénotypique de la variété ‘Picholine marocaine' dans la région du Haouz. Olivae 43: 30-33.

Calani L, Beghè D, Mena P, Del Rio D, Bruni R, Fabbri A, Dall'Asta C, Galaverna G. 2013. Ultra-HPLC-MSn (poly) phenolic profiling and chemometric analysis of juices from ancient Punica granatum L. cultivars: A nontargeted approach. Journal of Agricultural and Food Chemistry 61: 5600-5609.

Caliskan, O, Bayazit, O. 2013. Morpho-pomological and Chemical Diversity of Pomegranate Accessions Grown in Eastern Mediterranean Region of Turkey. Journal of Agricultural Science and Technology 15: 1449-1460 
347 Cam M, Hisil Y, Durmaz G. 2009. Characterisation of pomegranate juices from ten cultivars 348 grown in Turkey. International Journal of Food Properties 12: 388-395.

349 Ebrahimi S, Sayed-Tabatabaei BE, Sharifnabi B. 2010. Microsatellite isolation and 
Mars M, Marrakchi M. 1999. Diversity of pomegranate (Punica granatum L.) germplasm in Tunisia. Genetic Resources and Crop Evolution 46: 461-467.

Martínez JJ, Hernández F, Abdelmajid H, Legua P, Martínez R, El Amine A, Melgarejo P. 2012. Physico-chemical characterization of six pomegranate cultivars from Morocco: processing and fresh market aptitudes. Scientia Horticulturae 140: 100-106.

Martínez JJ, Melgarejo P, Hernández Fca, Legua P, Martínez-Font R. 2009. Pollen-pistil affinity of eigth new pomegranate clones (Punica granatum L.). Acta Horticulturae 818: 175-180.

Martínez JJ, Melgarejo P, Hernández Fca, Salazar DM, Martínez R. 2006. Seed characterisation of five new pomegranate (Punica granatum L.) varieties. Scientia Horticulturae 110: 241-246.

Melgarejo P, Artés F. 2000. Total lipid content and fatty acid composition of oil seeds from lesser known sweet pomegranate clones. Journal of the Science of Food and Agriculture 80: $1452-1456$.

Melgarejo P, Martínez JJ, Hernández Fca, Martínez R, Legua P, Oncina R, Martínez-Murcia A. 2009. Cultivar identification using $18 \mathrm{~S}-28 \mathrm{~S}$ rDNA intergenic spacer-RFLP in pomegranate (Punica granatum L.). Scientia Horticulturae 120: 500-503.

Melgarejo P, Salazar DM. 2003. Tratado de fruticultura para zonas áridas y semiáridas, Vol. II: Algarrobo, granado y jinjolero. Mundi-Prensa y AMV Ediciones. Madrid.

Melgarejo P. 1993. Selección y tipificación varietal de granado (Punica granatum L.). Tesis Doctoral. U.P.V. (Valencia).

Melgarejo-Sánchez P, Martínez JJ, Legua P, Martínez R, Hernández Fca, Melgarejo P. 2015. Quality, antioxidant activity and total phenols of six Spanish pomegranates clones. Scientia Horticulturae 182: 65-72. 
Mostafa S, Valizadehghan S, Mardi M, Reza M, Mahmoodi P, Zahravi M, Zeinalabedin M, Mojtaba S. 2010. Isolation and Characterization of Novel Microsatellite Markers in Pomegranate (Punica granatum L.). International Journal of Molecular Sciences 11: 20102016.

Naeini M R, Amir Khoshgoftarmanesh H, Lessani, H, Fallahi, E. 2004. Effects of Sodium Chloride-Induced Salinity on Mineral Nutrients and Soluble Sugars in Three Commercial Cultivars of Pomegranate. Journal of Plant Nutrition, 27, No. 8: 1319-1326.

Naeini M R, Khoshgoftarmanesh A H, Fallahi E. 2006. Partitioning of Chlorine, Sodium, and Potassium and Shoot Growth of Three Pomegranate Cultivars Under Different Levels of Salinity. Journal of Plant Nutrition 29: 1835-1843.

Narzary D, Mahar K S, Rana T S, Ranade SA. 2009. Analysis of genetic diversity among wild pomegranates in Western Himalayas, using PCR methods. Scientia Horticulturae 121: 237242

Ophir R, Sherman A, Rubinstein M, Eshed R, Sharabi Schwager M, Harel-Beja R, Bar-Ya'akov I, Holland D. 2014. Single-Nucleotide Polymorphism Markers from De-Novo Assembly of the Pomegranate Transcriptome Reveal Germplasm Genetic Diversity. PloS one 9 (2):e88998. doi:10.1371/journal.pone.0088998.

Papadakis J. 1966. Climates of the world and their agricultural potentialities. Symposium on Potential Productivity of Field Crops Under Different Environments, Buenos Aires, Argentina. $174 \mathrm{p}$.

Radunic M, Jukic M, Goreta S, Gadze J, Diaz-Perez JC, MacLean D. 2015. Physical and chemical properties of pomegranate fruit accessions from Croatia. Food Chemistry 177: $53-60$. 
418 Sarkhosh A, Zamani Z, Fatahi R, Ranjbar H. 2009. Evaluation of genetic diversity among 419 Iranian soft-seed pomegranate accessions by fruit characteristics and RAPD markers. $420 \quad$ Scientia Horticulturae 121: 313-319.

421 Sarkhosh, A, Zamani, Z, Fatahi, R, Ebadi, A. 2006. RAPD markers reveal polymorphism 422 among some Iranian pomegranate (Punica granatum L.) genotypes. Scientia Horticulturae 111: 24-29.

Singh NV, Abburi VL, Ramajayam D, Kumar R, Chandra R, Sharma KK, Sharma J, Babu KD, Pal RK, Mundewadikar DM, Saminathan T, Cantrell R, Nimmakayala P, Reddy UK. 2015. Genetic diversity and association mapping of bacterial blight and other horticulturally important traits with microsatellite markers in pomegranate from India. Molecular Genetics and Genomics 290 (4):1393-1402.

Tehranifar, A, Zarei, M, Nemati, Z, Esfandiyari, B, Vasifeshenas, MR. 2010. Investi-gation of physico-chemical properties and antioxidant activity of twenty Iranian pomegranate (Punica granatum L.) cultivars. Scientia Horticulturae 126: 180-185.

Tous J, Battle I, Romero A. 1995. Prospection de variedades de algarrobo en Andalucía. ITEA 91V: 164-174.

Verma N, Mohanty A, Lal A. 2010. Pomegranate genetic resources and germplasm conservation: a review. Fruit, Vegetable and Cereal Science and Biotechnology 4 (Special Issue 2): 120-125.

Zaouay F; Mena P; Garcia-Viguera C; Mars M. 2012. Antioxidant activity and physicochemical properties of Tunisian grown pomegranate (Punica granatum L.) cultivars. Industrial Crops and Products 40: 81-89.

Zhao L, Li M, Cai G, Pan T, Shan C. 2013. Assessment of the genetic diversity and genetic relationships of pomegranate (Punica granatum L.) in China using RAMP markers. Scientia Horticulturae 151: 63-67. 
443 Zhu J. 2002. Genetics, 3rd ed. China Agriculture Press, Beijing, pp. 249-314. 
444

445

446

447

448

449

450

451

452

453

454

455

456

457

458

\section{Figure Legends}

Figure 1. Location of the areas of origin of the accessions that comprised the germplasm collection studied. The name of each accession according to the codes used can be found in Table 1.

Figure 2. Plot of the principal components PC1-PC2 (Figure 2A), PC1-PC3 (Figure 2B) and PC2-PC3 (Figure 2C) showing dispersion of Spanish pomegranates, based on morphological characteristics of the fruit and leaves, and the $\mathrm{pH}$ and acidity of the juice. Each color indicates a group of varieties of similar characteristics.

Figure 3. Cluster analysis grouping of 53 Spanish pomegranate cultivars (See Table 1 for cultivars names abbreviations). Each color indicates a group of varieties of similar characteristics. 


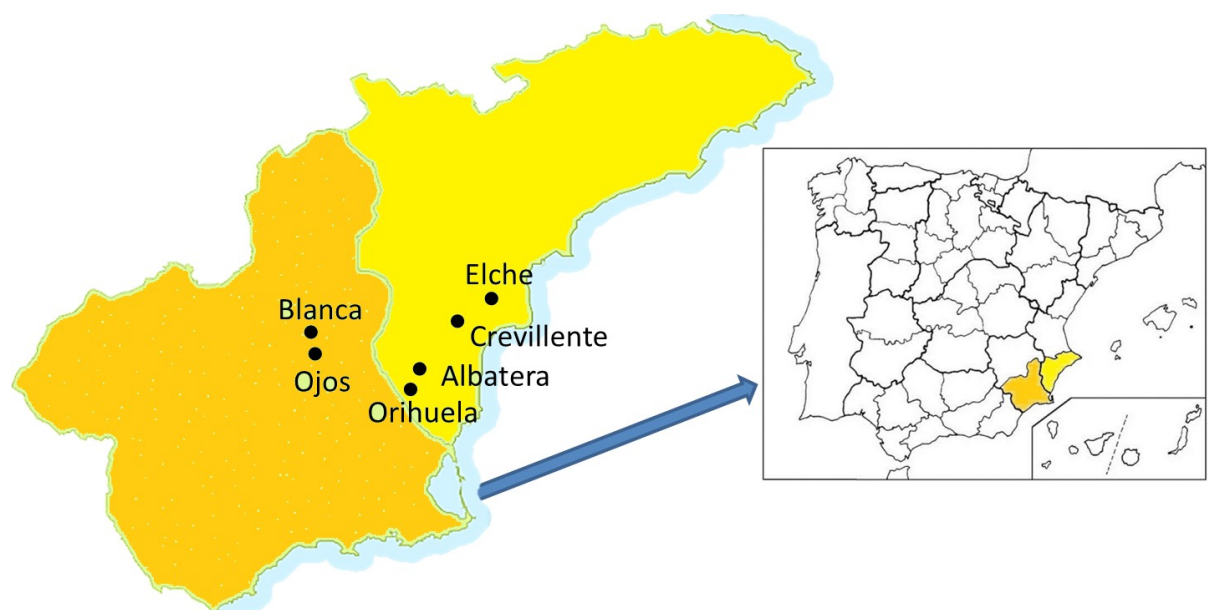

\begin{tabular}{|c|c|}
\hline $\begin{array}{c}\text { Blanca } \\
\mathrm{AB} 1 \text {, SFB1, } \mathrm{PB} 1\end{array}$ & $\begin{array}{c}\text { Albatera } \\
\text { BA1, MA1, MA2, MA3, MA4, MA5 }\end{array}$ \\
\hline $\begin{array}{l}\text { Crevillente } \\
\text { MC1, VA1 }\end{array}$ & $\begin{array}{c}\text { Ojos: } \\
\text { ADO2, ADO3, BO1, CRO1, CRO2, PDO2, PTO2, } \\
\text { PTO3, PTO4, PTO5, PTO6, PTO7, PTO8 }\end{array}$ \\
\hline $\begin{array}{c}\text { Elche } \\
\text { ME1, ME2, ME3, ME3.1, ME4, ME5, ME6, ME7, } \\
\text { ME8, ME9, ME10, ME11, ME12, ME13, ME14, } \\
\text { ME15, ME16, ME17, ME18, ME19, ME20, ME21 }\end{array}$ & $\begin{array}{c}\text { Orihuela } \\
\mathrm{MO} 2, \mathrm{MO} 3, \mathrm{MO} 4, \mathrm{MO} \text {, MO6 }\end{array}$ \\
\hline
\end{tabular}

Figure 1. Location of the areas of origin of the accessions that comprise the germplasm 461 collection studied. The name of each accession according to the codes used can be found in Table 1. 

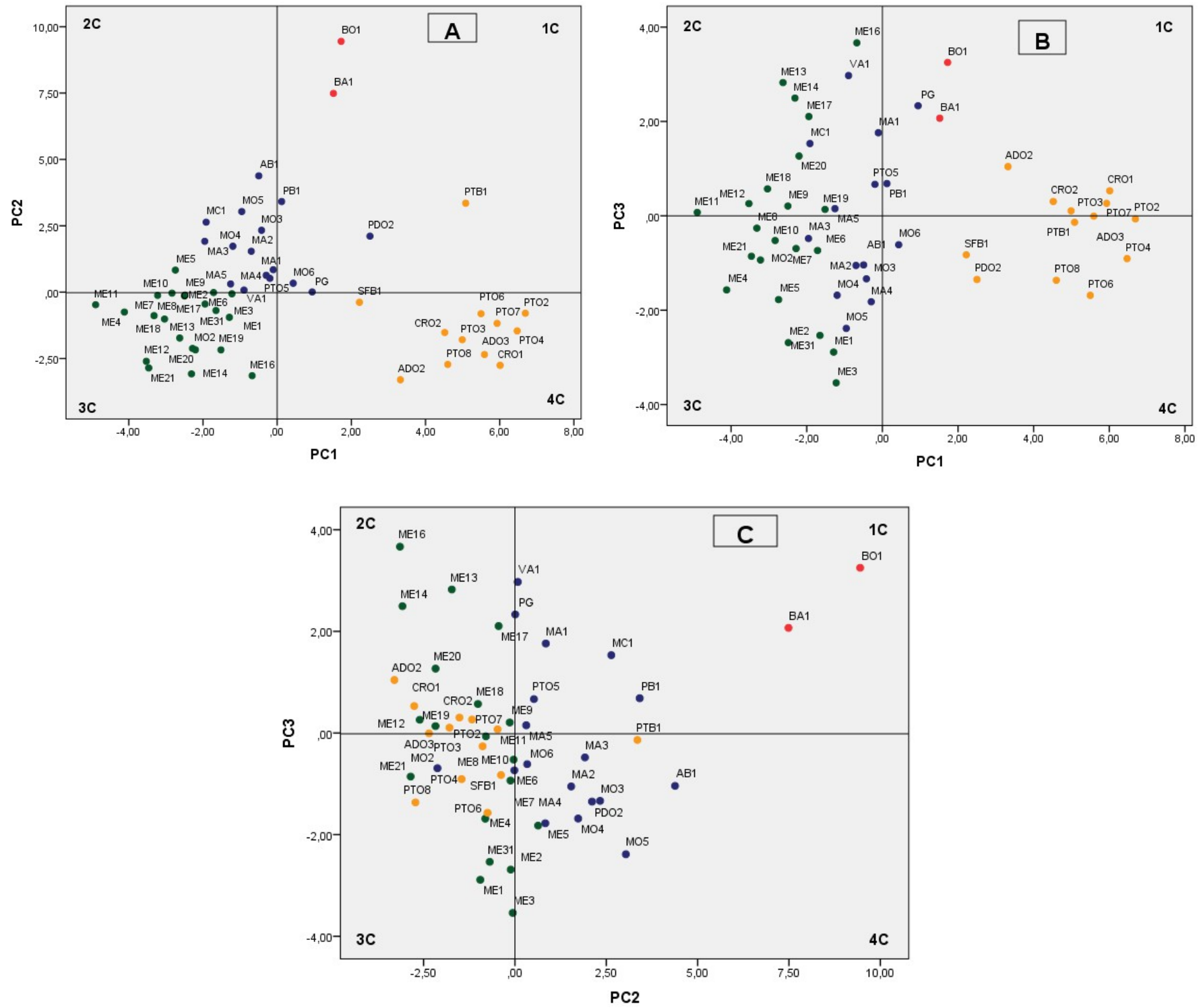

Figure 2. Plot of the principal components PC1-PC2 (Figure 2A), PC1-PC3 (Figure 2B) and

472 PC2-PC3 (Figure 2C) showing dispersion of Spanish pomegranates, based on morphological 473 characteristics of the fruit and leaves, and the $\mathrm{pH}$ and acidity of the juice. Each color indicates a group of varieties of similar characteristics. 


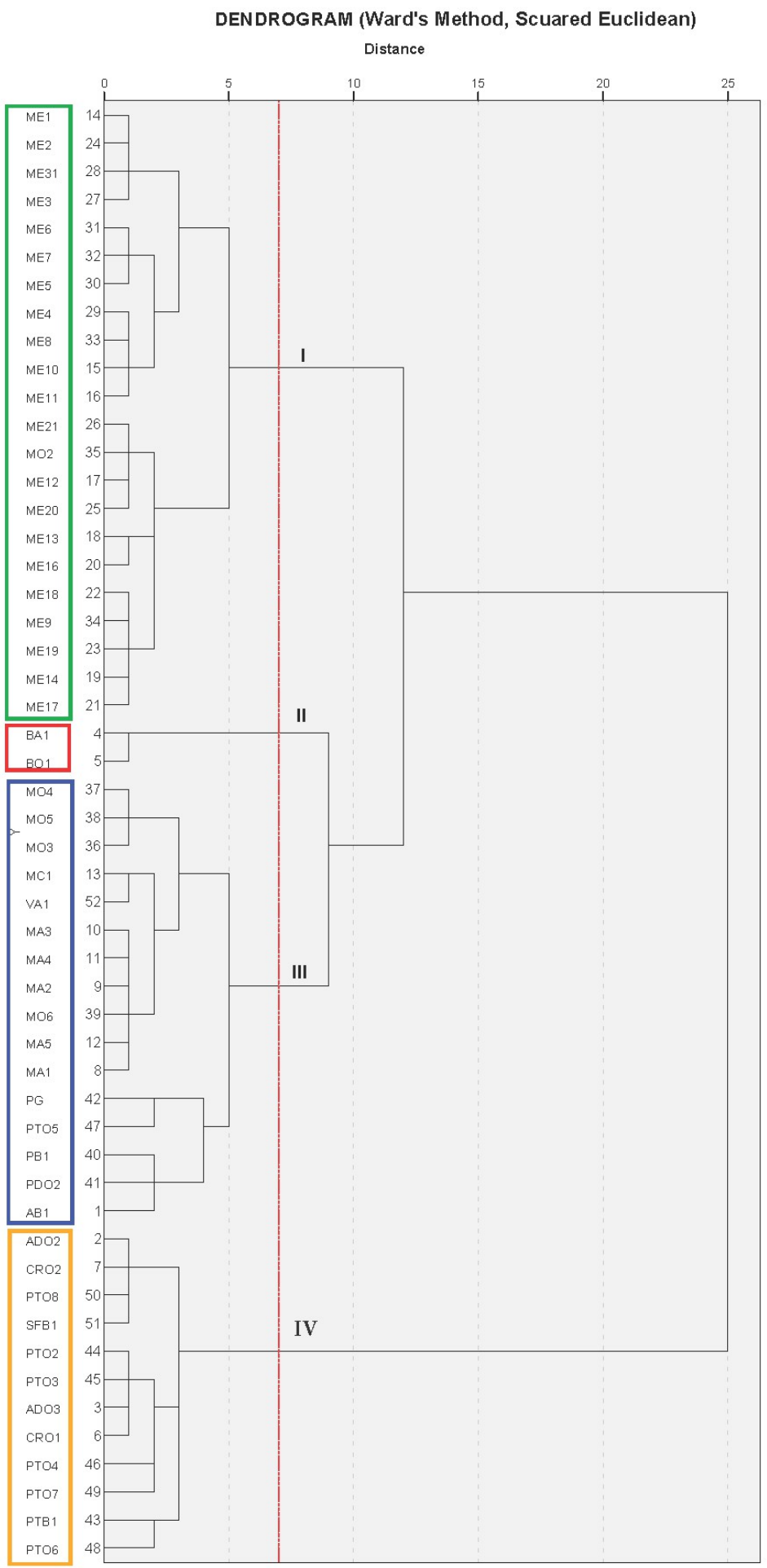

476 Figure 3. Cluster analysis grouping of 53 Spanish pomegranate cultivars (See Table 1 for cultivars names abbreviations). Each color indicates a group of varieties of similar characteristics.

478 Table 1. Names, abbreviations and origin of pomegranate accessions evaluated. 


\begin{tabular}{|c|c|c|c|c|c|}
\hline $\mathrm{AB} 1$ & Albar de Blanca 1 & Blanca (Murcia) & ME13 & Mollar de Elche 13 & Elche (Alicante) \\
\hline $\mathrm{ADO} 2$ & Agridulce de Ojós 2 & Ojos (Murcia) & ME14 & Mollar de Elche 14 & Elche (Alicante) \\
\hline $\mathrm{ADO} 3$ & Agridulce de Ojós 3 & Ojos (Murcia) & ME16 & Mollar de Elche 16 & Elche (Alicante) \\
\hline BA1 & Borde de Albatera 1 & Albatera (Alicante) & ME17 & Mollar de Elche 17 & Elche (Alicante) \\
\hline BO1 & Borde de Ojós 1 & Ojos (Murcia) & ME18 & Mollar de Elche 18 & Elche (Alicante) \\
\hline CRO1 & Casta del Reino 1 & Ojos (Murcia) & ME19 & Mollar de Elche 19 & Elche (Alicante) \\
\hline CRO2 & Casta del Reino 2 & Ojos (Murcia) & ME20 & Mollar de Elche 20 & Elche (Alicante) \\
\hline MA1 & Mollar de Albatera 1 & Albatera (Alicante) & ME21 & Mollar de Elche 21 & Elche (Alicante) \\
\hline MA2 & Mollar de Albatera 2 & Albatera (Alicante) & MO2 & Mollar de Orihuela 2 & Orihuela (Alicante) \\
\hline MA3 & Mollar de Albatera 3 & Albatera (Alicante) & MO3 & Mollar de Orihuela 3 & Orihuela (Alicante) \\
\hline MA4 & Mollar de Albatera 4 & Albatera (Alicante) & MO4 & Mollar de Orihuela 4 & Orihuela (Alicante) \\
\hline MA5 & Mollar de Albatera 5 & Albatera (Alicante) & MO5 & Mollar de Orihuela 5 & Orihuela (Alicante) \\
\hline $\mathrm{MC1}$ & Molar de Crevillente & Crevillente (Alicante) & MO6 & Mollar de Orihuela 6 & Orihuela (Alicante) \\
\hline ME1 & Mollar de Elche 1 & Elche (Alicante) & PB1 & Piñonenca de Blanca 1 & Blanca (Murcia) \\
\hline ME2 & Mollar de Elche 2 & Elche (Alicante) & PDO2 & Piñón duro de Ojós 2 & Ojos (Murcia) \\
\hline ME3 & Mollar de Elche 3 & Elche (Alicante) & $\mathrm{PG}$ & Puente Genil & Puente Genil (Córdoba) \\
\hline ME3.1 & Mollar de Elche 3.1 & Elche (Alicante) & PTB1 & Piñón tierno de Blanca 1 & Blanca (Murcia) \\
\hline ME4 & Mollar de Elche 4 & Elche (Alicante) & PTO2 & Piñón tierno de Ojós 2 & Ojos (Murcia) \\
\hline ME5 & Mollar de Elche 5 & Elche (Alicante) & PTO3 & Piñón tierno de Ojós 3 & Ojos (Murcia) \\
\hline ME6 & Mollar de Elche 6 & Elche (Alicante) & PTO4 & Piñón tierno de Ojós 4 & Ojos (Murcia) \\
\hline ME7 & Mollar de Elche 7 & Elche (Alicante) & PTO5 & Piñón tierno de Ojós 5 & Ojos (Murcia) \\
\hline ME8 & Mollar de Elche 8 & Elche (Alicante) & PTO6 & Piñón tierno de Ojós 6 & Ojos (Murcia) \\
\hline ME9 & Mollar de Elche 9 & Elche (Alicante) & PTO7 & Piñón tierno de Ojós 7 & Ojos (Murcia) \\
\hline ME10 & Mollar de Elche 10 & Elche (Alicante) & PTO8 & Piñón tierno de Ojós 8 & Ojos (Murcia) \\
\hline ME11 & Mollar de Elche 11 & Elche (Alicante) & SFB1 & San Felipe de Blanca 1 & Blanca (Murcia) \\
\hline ME12 & Mollar de Elche 12 & Elche (Alicante) & VA1 & Valenciana de Albatera 1 & Albatera (Alicante) \\
\hline
\end{tabular}


Table 2. Mean values of fruit characters of each varietal group

\begin{tabular}{|c|c|c|c|c|c|c|c|c|c|c|c|c|c|c|c|c|c|c|}
\hline & \multicolumn{3}{|c|}{$\mathrm{ADO}$} & \multicolumn{3}{|c|}{ CRO } & \multicolumn{3}{|c|}{ MA } & \multicolumn{3}{|c|}{ ME } & \multicolumn{3}{|c|}{ MO } & \multicolumn{3}{|c|}{ PTO } \\
\hline Variable & Mean & Min & Max & Mean & Min & Max & Mean & Min & Max & Mean & Min & Max & Mean & Min & Max & Mean & Min & Max \\
\hline FW & 409 & 207 & 747 & 414 & 219 & 824 & 358 & 172 & 584 & 325 & 125 & \begin{tabular}{|l|}
613 \\
\end{tabular} & 366 & 147 & 609 & 407 & 191 & 753 \\
\hline FD1 & 93 & 75 & 116 & 96 & 74 & 118 & 89 & 68 & 109 & 86 & 60 & 111 & 90 & 65 & 110 & 93 & 70 & 120 \\
\hline FD2 & 19 & 13 & 27 & 20 & 15 & 25 & 21 & 15 & 30 & 21 & 9 & 32 & 21 & 12 & 32 & 19 & 11 & 30 \\
\hline FL1 & 79 & 63 & 99 & 80 & 54 & 105 & 77 & 59 & 100 & 74 & 51 & 99 & 77 & 57 & 92 & 80 & 60 & 99 \\
\hline FL2 & 97 & 72 & 115 & 98 & 75 & 120 & 92 & 68 & 110 & 91 & 67 & 112 & 93 & 66 & 109 & 97 & 74 & 117 \\
\hline FL3 & 19 & 3 & 26 & 18 & 9 & 29 & 15 & 2 & 32 & 16 & 1 & 30 & 16 & 6 & 25 & 17 & 4 & 26 \\
\hline $\mathrm{Nc}$ & 6 & 5 & 9 & 7 & 5 & 8 & 7 & 5 & 8 & 7 & 5 & 9 & 7 & 5 & 9 & 6 & 5 & 8 \\
\hline PcMc & 143 & 75 & 214 & 155 & 83 & 272 & 154 & 80 & 265 & 142 & 60 & 289 & 150 & 68 & 247 & 150 & 73 & 272 \\
\hline Ec & 3 & 2 & 5 & 3 & 1 & 6 & 4 & 2 & 6 & 4 & 1 & 8 & 3 & 1 & 6 & 3 & 1 & 6 \\
\hline Rs & 64 & 39 & 76 & 62 & 48 & 72 & 56 & 40 & 74 & 56 & 37 & 72 & 58 & 40 & 71 & 62 & 43 & 73 \\
\hline
\end{tabular}

481

482

483

484

485

486

487

488

489 Table 5. Analysis of variance of each variable analyzed within each group of varieties studied

Table 3. Mean values of aril, seed and juice characteristics of each varietal group

For explanation of character symbols, see Material and methods

Table 4. Mean values of leaf and flowers characteristics of each varietal group

For explanation of character symbols, see Material and methods

\begin{tabular}{|c|r|r|r|r|r|r|r|r|r|r|r|r|r|r|r|r|r|r|}
\hline & \multicolumn{4}{|c|}{ ADO } & \multicolumn{4}{|c|}{ CRO } & \multicolumn{4}{|c|}{ MA } & \multicolumn{4}{|c|}{ MO } \\
\hline Variable & Mean & Min & Max & Mean & Min & Max & Mean & Min & Max & Mean & Min & Max & Mean & Min & Max & Mean & Min & Max \\
\hline SW & 0,55 & 0,16 & 0,84 & 0,63 & 0,38 & 0,85 & 0,40 & 0,18 & 0,71 & 0,39 & 0,15 & 0,62 & 0,41 & 0,18 & 0,68 & 0,55 & 0,13 & 0,81 \\
\hline SL & 12,8 & 7,2 & 15,8 & 12,7 & 8,4 & 16,4 & 10,3 & 6,2 & 13,3 & 10,3 & 1,2 & 14,2 & 10,4 & 5,2 & 13,8 & 12,4 & 6,5 & 17,2 \\
\hline Sw & 7,22 & 3,50 & 10,23 & 7,66 & 4,90 & 10,22 & 6,63 & 3,40 & 9,84 & 6,48 & 1,89 & 11,15 & 6,31 & 2,99 & 10,79 & 7,20 & 2,61 & 11,74 \\
\hline 1 & 7,16 & 0,41 & 9,99 & 7,38 & 4,65 & 10,62 & 6,40 & 2,98 & 10,23 & 6,11 & 2,10 & 9,96 & 6,02 & 3,14 & 9,04 & 7,71 & 3,46 & 14,88 \\
\hline w & 1,94 & 0,43 & 3,41 & 2,24 & 0,90 & 3,93 & 2,21 & 0,34 & 4,37 & 1,96 & 0,20 & 4,54 & 1,72 & 0,48 & 4,17 & 2,12 & 0,13 & 4,44 \\
\hline wpw & 0,04 & 0,02 & 0,08 & 0,05 & 0,01 & 0,09 & 0,04 & 0,01 & 0,08 & 0,04 & 0,01 & 0,10 & 0,04 & 0,02 & 0,09 & 0,04 & 0,02 & 0,08 \\
\hline wpi & 7,75 & 3,30 & 18,20 & 7,98 & 1,37 & 15,82 & 10,23 & 3,63 & 21,01 & 10,14 & 2,18 & 22,05 & 10,09 & 4,31 & 21,45 & 7,75 & 3,30 & 18,20 \\
\hline JV & 51,8 & 42,0 & 61,0 & 59,5 & 48,0 & 64,0 & 52,7 & 31,0 & 64,0 & 51,7 & 34,0 & 65,0 & 49,5 & 35,0 & 60,0 & 56,2 & 47,0 & 65,0 \\
\hline pH & 3,78 & 3,11 & 4,10 & 3,93 & 3,82 & 4,01 & 3,98 & 3,62 & 4,23 & 4,05 & 2,62 & 5,94 & 4,03 & 3,94 & 4,11 & 3,72 & 2,89 & 4,10 \\
\hline TSS & 13,7 & 12,0 & 15,2 & 12,6 & 10,9 & 13,2 & 15,3 & 13,8 & 17,0 & 14,6 & 12,3 & 19,8 & 14,7 & 12,4 & 16,9 & 14,0 & 12,0 & 16,3 \\
\hline A & 0,42 & 0,26 & 0,90 & 0,31 & 0,28 & 0,35 & 0,23 & 0,20 & 0,31 & 0,24 & 0,17 & 0,92 & 0,21 & 0,16 & 0,28 & 0,48 & 0,26 & 1,46 \\
\hline MI & 40,5 & 17,0 & 49,6 & 41,6 & 37,0 & 47,2 & 68,7 & 50,8 & 80,5 & 65,3 & 16,3 & 87,2 & 72,2 & 54,7 & 85,1 & 37,6 & 8,2 & 58,0 \\
\hline
\end{tabular}

\begin{tabular}{|c|r|r|r|r|r|r|r|r|r|r|r|r|r|r|r|r|r|r|r|}
\hline & \multicolumn{4}{|c|}{ ADO } & \multicolumn{4}{|c|}{ CRO } & \multicolumn{4}{|c|}{ MA } & \multicolumn{4}{|c|}{ ME } & \multicolumn{3}{|c|}{ PTO } \\
\hline Variable & Mean & Min & Max & Mean & Min & Max & Mean & Min & Max & Mean & Min & Max & Mean & Min & Max & Mean & Min & Max \\
\hline LW & 19,9 & 11,3 & 30,8 & 19,1 & 12,9 & 26,9 & 22,4 & 13,6 & 31,0 & 21,1 & 9,8 & 34,0 & 22,4 & 10,5 & 33,6 & 20,0 & 11,4 & 33,3 \\
\hline Ll & 53,2 & 28,6 & 89,0 & 51,3 & 26,1 & 74,7 & 54,7 & 33,9 & 89,0 & 51,5 & 24,1 & 88,9 & 54,1 & 22,9 & 85,9 & 50,6 & 22,4 & 87,4 \\
\hline Lt & 58,6 & 34,2 & 95,8 & 56,6 & 31,6 & 82,6 & 60,8 & 38,5 & 95,3 & 57,1 & 27,7 & 97,3 & 60,0 & 28,6 & 95,4 & 55,6 & 27,6 & 97,1 \\
\hline Lp & 5,38 & 2,42 & 9,40 & 5,31 & 1,83 & 10,01 & 6,11 & 1,86 & 10,73 & 5,58 & 1,65 & 10,63 & 5,90 & 2,05 & 10,67 & 5,03 & 1,65 & 10,61 \\
\hline Ll/LW & 2,72 & 1,47 & 4,53 & 2,71 & 1,68 & 4,32 & 2,47 & 1,56 & 3,90 & 2,48 & 1,00 & 4,51 & 2,43 & 1,57 & 4,50 & 2,56 & 1,00 & 4,51 \\
\hline LS & 7,47 & 1,37 & 16,77 & 7,35 & 2,58 & 17,43 & 8,35 & 0,50 & 16,75 & 7,75 & 0,30 & 18,07 & 8,60 & 3,03 & 17,34 & 7,75 & 1,32 & 17,40 \\
\hline FD & 17,0 & 7,1 & 35,2 & 10,6 & 7,5 & 17,13 & 13,2 & 8,3 & 19,6 & 15,2 & 9,5 & 25,1 & 14,5 & 8,5 & 35,1 & 12,1 & 7,2 & 18,2 \\
\hline FL & 27,0 & 13,9 & 39,7 & 31,7 & 24,4 & 46,1 & 31,1 & 21,4 & 44,0 & 26,5 & 10,3 & 41,7 & 29,9 & 12,8 & 44,4 & 33,5 & 15,8 & 48,5 \\
\hline Np & 6,21 & 5,00 & 8,00 & 6,34 & 6,00 & 8,00 & 6,62 & 5,00 & 8,00 & 6,32 & 5,00 & 8,00 & 7,18 & 6,00 & 9,00 & 7,44 & 6,00 & 9,00 \\
\hline Lp & 19,6 & 15,2 & 24,3 & 21,2 & 17,8 & 25,4 & 22,3 & 18,5 & 27,2 & 22,1 & 15,1 & 30,0 & 22,5 & 15,4 & 28,4 & 20,9 & 14,6 & 28,5 \\
\hline Wp & 15,1 & 10,7 & 19,0 & 16,0 & 13,9 & 19,2 & 17,2 & 13,7 & 20,2 & 17,2 & 10,9 & 22,0 & 17,4 & 12,4 & 22,7 & 15,7 & 10,9 & 21,3 \\
\hline Ns & 6,21 & 5,00 & 8,00 & 6,34 & 6,00 & 8,00 & 6,66 & 6,00 & 8,00 & 6,32 & 5,00 & 8,00 & 7,18 & 6,00 & 9,00 & 7,44 & 6,00 & 9,00 \\
\hline LS & 12,2 & 2,7 & 28,8 & 12,4 & 2,9 & 28,2 & 19,2 & 5,2 & 30,8 & 12,5 & 1,4 & 39,2 & 16,4 & 2,8 & 30,8 & 13,4 & 3,0 & 28,7 \\
\hline NS & 348,5 & 216 & 510 & 332,6 & 218 & 476 & 327,3 & 204 & 512 & 245,8 & 108 & 372 & 337,5 & 168 & 532 & 343,5 & 204 & 526 \\
\hline
\end{tabular}




\begin{tabular}{|c|c|c|c|c|c|c|c|c|c|c|c|c|c|c|}
\hline & FW & FD1 & FD2 & FL1 & FL2 & FL3 & $\mathrm{Nc}$ & PcMc & $\mathrm{Ec}$ & & & Rs & & \\
\hline$A D O$ & $* *$ & $*$ & ns & $*$ & ns & $*$ & ns & ns & ns & & & $* *$ & & \\
\hline $\mathrm{CRO}$ & $* *$ & $*$ & ns & ns & ns & ns & ns & ns & ns & & & $*$ & & \\
\hline $\mathrm{MA}$ & ns & ns & $* * *$ & ns & ns & ns & ns & ns & $* *$ & & & $* *$ & & \\
\hline $\mathrm{ME}$ & $* * *$ & $* * *$ & $* * *$ & $* * *$ & $* * *$ & $* *$ & $* * *$ & $* *$ & $* * *$ & & & $* * *$ & & \\
\hline $\mathrm{MO}$ & ns & ns & ns & ns & ns & ns & ns & ns & ns & & & ns & & \\
\hline PTO & $* *$ & $* * *$ & $* *$ & $* *$ & $* * *$ & $* *$ & ns & $*$ & $* *$ & & & $* * *$ & & \\
\hline \multicolumn{15}{|c|}{ Aril, seed and juice characteristics } \\
\hline & SW & $\mathrm{SL}$ & Sw & 1 & $\mathrm{~W}$ & wpw & wpi & JV & $\mathrm{pH}$ & TSS & A & & MI & \\
\hline ADO & $* * *$ & $* * *$ & $* * *$ & $*$ & $* * *$ & $* *$ & $* * *$ & $*$ & ns & ns & ns & & $*$ & \\
\hline $\mathrm{CRO}$ & ns & $* *$ & ns & ns & ns & ns & ns & ns & ns & ns & ns & & $* *$ & \\
\hline MA & $* * *$ & $* * *$ & $*$ & $* * *$ & $* * *$ & $* * *$ & $* * *$ & ns & ns & ns & ns & & ns & \\
\hline $\mathrm{ME}$ & $* * *$ & $* * *$ & $* * *$ & $* * *$ & $* * *$ & $* * *$ & $* * *$ & $\mathrm{~ns}$ & ns & $\mathrm{ns}$ & ns & & $* *$ & \\
\hline $\mathrm{MO}$ & $\mathrm{ns}$ & $* *$ & $* *$ & $* * *$ & $*$ & $* * *$ & $* * *$ & $\mathrm{~ns}$ & ns & $\mathrm{ns}$ & ns & & $\mathrm{ns}$ & \\
\hline PTO & $* * *$ & $* * *$ & $* * *$ & $* * *$ & $* * *$ & $* * *$ & $* * *$ & ns & $* * *$ & $* *$ & $* * *$ & & $* * *$ & \\
\hline & Leafs & \multicolumn{13}{|c|}{ Flowers } \\
\hline & LW & $\mathrm{Ll}$ & $\mathrm{Lt}$ & $\mathrm{Lp}$ & $\mathrm{Ll} / \mathrm{LW}$ & LS & FD & $\mathrm{FL}$ & $\mathrm{Np}$ & $\mathrm{Lp}$ & $\mathrm{Wp}$ & Ns & LS & $\mathrm{NS}$ \\
\hline $\mathrm{ADO}$ & $* * *$ & $* * *$ & $* *$ & $\mathrm{~ns}$ & ns & $\mathrm{ns}$ & $* * *$ & $* * *$ & ns & $\mathrm{ns}$ & $* * *$ & ns & $\mathrm{ns}$ & ns \\
\hline $\mathrm{CRO}$ & $\mathrm{ns}$ & $* * *$ & $* * *$ & ns & $* *$ & $*$ & ns & ns & $* *$ & $* *$ & ns & $* *$ & ns & ns \\
\hline $\mathrm{MA}$ & $* *$ & $* *$ & $* *$ & $*$ & $* * *$ & $\mathrm{~ns}$ & $\mathrm{~ns}$ & $* * *$ & $* * *$ & $* * *$ & $* * *$ & $* * *$ & $\mathrm{~ns}$ & $* * *$ \\
\hline $\mathrm{ME}$ & $* * *$ & $* * *$ & $* * *$ & $* * *$ & $* * *$ & $* * *$ & $* * *$ & $* * *$ & $* * *$ & $* * *$ & $* * *$ & $* * *$ & $* * *$ & $* * *$ \\
\hline $\mathrm{MO}$ & $* * *$ & $* * *$ & $* * *$ & $* * *$ & $* * *$ & * & $* * *$ & $* * *$ & $* * *$ & $* * *$ & $* * *$ & $* * *$ & $* * *$ & $* * *$ \\
\hline PTO & $* * *$ & $* * *$ & $* * *$ & $* * *$ & $* * *$ & $* * *$ & $* * *$ & $* * *$ & $* * *$ & $* * *$ & $* * *$ & $* * *$ & $* * *$ & $* * *$ \\
\hline
\end{tabular}

$490 *, * *, * * *$ and 'ns' indicate significant differences at $\mathrm{P}<0.05, \mathrm{P}<0.01, \mathrm{P}<0.001$ levels as well as non-significant, respectively. For explanation of character symbols, see Material and methods 
494 Table 6. Eigenvalues, proportion of variation and eigenvectors associated with three axes of the

495 PCA in pomegranate germplasm.

496

\begin{tabular}{|c|c|c|c|}
\hline Principal components (axes) & 1 & 2 & 3 \\
\hline Cumulated proportion of variation & 27.77 & 45.26 & 53.75 \\
\hline Characters & \multicolumn{3}{|c|}{ Eigenvectors } \\
\hline FW & 0.28 & 0.06 & -0.01 \\
\hline FD1 & 0.28 & 0.07 & -0.01 \\
\hline FD2 & -0.15 & 0.07 & -0.19 \\
\hline FL1 & 0.26 & 0.09 & -0.03 \\
\hline FL2 & 0.27 & 0.09 & 0.01 \\
\hline FL3 & 0.11 & 0.03 & 0.11 \\
\hline $\mathrm{Nc}$ & -0.12 & 0.02 & 0.15 \\
\hline PcMc & 0.11 & 0.26 & -0.18 \\
\hline Ec & -0.16 & 0.08 & -0.24 \\
\hline Rs & 0.22 & -0.17 & 0.17 \\
\hline SW & 0.25 & -0.15 & 0.07 \\
\hline SL & 0.27 & -0.15 & 0.05 \\
\hline Sw & 0.19 & -0.17 & 0.09 \\
\hline 1 & 0.25 & -0.02 & 0.05 \\
\hline $\mathrm{W}$ & 0.11 & 0.07 & 0.13 \\
\hline wpw & 0.13 & 0.12 & 0.11 \\
\hline wpi & -0.13 & 0.25 & 0.01 \\
\hline LW & -0.14 & 0.17 & 0.31 \\
\hline $\mathrm{Ll}$ & 0.02 & 0.28 & -0.16 \\
\hline $\mathrm{Lt}$ & 0.01 & 0.28 & -0.15 \\
\hline $\mathrm{Lp}$ & -0.10 & 0.18 & 0.03 \\
\hline L1/LW & 0.12 & 0.07 & -0.38 \\
\hline $\mathrm{LS}$ & -0.01 & 0.22 & 0.15 \\
\hline FD & -0.19 & 0.11 & 0.20 \\
\hline $\mathrm{FL}$ & 0.17 & 0.21 & 0.23 \\
\hline NP & 0.16 & 0.17 & 0.20 \\
\hline LP & -0.10 & 0.24 & 0.12 \\
\hline WP & -0.11 & 0.18 & 0.25 \\
\hline $\mathrm{Ns}$ & 0.16 & 0.18 & 0.20 \\
\hline $\mathrm{LS}$ & -0.01 & 0.29 & 0.14 \\
\hline NS & 0.16 & 0.11 & -0.06 \\
\hline JV & 0.12 & -0.01 & 0.15 \\
\hline $\mathrm{pH}$ & -0.10 & -0.22 & 0.22 \\
\hline TSS & -0.10 & 0.08 & 0.14 \\
\hline $\mathrm{AT}$ & 0.08 & 0.25 & -0.20 \\
\hline MI & -0.19 & -0.12 & 0.23 \\
\hline
\end{tabular}

497 For explanation of character symbols, see Material and methods 